\title{
New group of oligosaccharides excreted in honeydew from scale insects Stigmacoccus sp. And coccus hesperidium L.
}

\author{
Novo grupo de oligossacarídeos excretado no "honeydew" das \\ cochonilhas Stigmacoccus sp. E coccus hesperidum L.
}

\author{
Amauri Bogo 1
}

\section{ABSTRACT}

Analysis of the honeydew from scale insects Stigmacoccus sp. and Coccus hesperidium (L.) were carried out by paper chromatography, FAB-MS and GC-MS. The results showed three components (tri-, tetra- and pentasaccharides) which were composed by 1,4 glucose(s) linked to the glucose of sucrose. The findings therefore imply significant and novel metabolic transformations of sugars by the insect and/or microbial symbionts. From these results, structures and common names as "Stigmatriose, Stigmatetraose and Stigmapentose" were proposed for these oligosaccharides because they were found initially in Stigmacoccus sp. honeydew.

Key words: Homoptera, oligosaccharides, FAB-MS, CG-MS, structures.

\section{RESUMO}

Análise da secreção doce ou açucarada produzida pelas cochonilhas Stigmacoccus sp. e Coccus hesperidium (L.) foi realizada pelas técnicas de cromatografia de papel, bombardeamento de átomo rápido-espectrometria de massas (FAB-MS) e cromatografia gasosa-espectrometria de massas (GC-MS). Os resultados mostraram a presença de três oligossacarideos (tri-, tetra- e pentassacarídeos) os quais são compostos por uma ou mais moléculas de 1,4glucopiranose ligadas à posição 1-glucopiranose do dissacarídeo sacarose. A constatação da presença destes oligossacarídeos na secreção doce ou açucarada das espécies citadas sugere um significante e novo metabolismo de transformação de açucares pelo inseto elou por simbiontes microbianos. A partir destes resultados, e por não existirem referências sobre o assunto, sugerem-se as fórmulas estruturais e os nomes comuns de "Estigmatriose, Estigmatetraose e Estigmapentaose" pelo fato de terem sido inicialmente encotrados no honeydew de Stigmacoccus sp.

Palavras-chave: Homoptera, oligosacarideos, FAB-MS, $C G-M S$, estruturas.

\section{INTRODUCTION}

Scale insects feeding on plant phloem sugars excrete a syrup termed honeydew, as in ergot disease, which contains several oligosaccharides. The synthesis of these oligosaccharides from sucrose by transglucosylation reactions has been proposed as an osmoregulatory mechanism in these insects (FISHER et al., 1984).

Little is known about the composition of the honeydew secreted by Coccoidea, and particularly nothing appears to have been published, based on modern analytical techniques, on the honeydew produced by insects of the genus Stigmacoccus and also even of the common Coccus hesperidum L. Concerning the latter, WHITE \& MAHER (1953) described a maltosyl-fructofuranoside arising by glucosyl transfer to sucrose. GRAY \& FRAENKEL (1953) implied that this "fructomaltose" was widely associated with scale insects, aphids and bees.

Most of the studies on scale insect honeydew oligosaccharides have concentrated on

${ }^{1}$ Engenheiro Agrônomo, MSc, PhD em Fitopatologia e Bioquímica, Professor do Departamento de Fitotecnia, Centro de Ciências Agroveterinárias, (CAV), Universidade do Estado de Santa Catarina (UDESC). Avenida Luis de Camões, 2090, Bairro Conta Dinheiro, 88520-000, Lages-SC. Brasil. E-mail: a2ab@cav.udesc.br. Autor para correspondência. 
Homoptera: Aleyrodidae such as Bemisia sp. (whiteflies), in which the unusual disaccharide trehalulose was first identified in B. tabaci (BYRNE \& MILLER, 1990). Later, HENDRIX \& WEI (1994) identified bemisiose as another B. tabaci unusual trisaccharide. ISAACS et al. (1998), studying the composition of cucurbit phloem sap and B. tabaci honeydew, suggested that glucose made up $60 \%$ of the honeydew sugars. The cucurbit plant sap contained low levels of sucrose and raffinose. However, no sucrose or melezitose were detected in any honeydew samples. DAVIDSON et al. (1994) suggested that the unusual disaccharide trehalulose, an important constituent in honeydew of $\boldsymbol{B}$. argentifolii, is produced by obligate intracellular microorganisms residing in this insect's mycetomes. Some larger oligosaccharides in this honeydew may be produced by certain Bacillus spp. residing in or on the insects, and may contribute with artefacts to the composition of honeydew collected from rather heterogeneous surfaces. Such bacteria are not involved in an obligate relationship with the insect (DAVIDSON et al., 1994). Consequently, the observation of the uncontaminated excretion of honeydew on long (ca. $5 \mathrm{~cm}$ ) hyaline anal extensions of an yet undescribed species of genus Stigmacoccus, though near $\boldsymbol{S}$. asper Hempel (BOGO et al., 1999), prompted the application of modern linkage analysis methodology to define the composition of the oligosaccharides which arise entirely from enteric transformation of the plant sugars, sucrose and glucose, ingested by the scale insect in phloem sap.

\section{MATERIALS AND METHODS}

Honeydew from scale insect Stigmacoccus sp. infesting Schizolobium excelsum (leguminous native from Amazonia) and Coccus hesperidum (L.) infecting Hedera sp. (ornamental garden) were collected $(10-20 \mu \mathrm{l})$ separately by capillarity into glass tubes.

\section{Oligosaccharides isolation}

Whatman No. 3 MM paper was used for the isolation of sugars. The solvent system used was propan-1-ol: ethyl acetate: water $(7: 1: 2)$. For preparative isolation of sugars, viscous honeydew and standards (fructose, glucose, sucrose and raffinose) were diluted by 10 times and then loaded onto the paper as a spot $(100 \mu 1)$ and run for 48-55 hours. To elucidate qualitatively the honeydew sugars, the air dried chromatogram was taken through a dip tank, containing aniline hydrogen phthalate reagent (BOGO,
2001). After drying, the paper was heated at $120^{\circ} \mathrm{C}$ in an oven for $20 \mathrm{~min}$. Oligosaccharides were eluted preparatively in warm water, repurified where necessary, and freeze-dried prior to saccharide analysis and bioassay.

Linkage analysis. Oligosaccharide composition was determined by a combination of FABMS analysis of permethylated derivatives (DELL et al., 1994) and GC-MS analysis after the standard procedure of hydrolysis, reduction and peracetylation had been applied to the permethylated saccharides (CARPITA \& SHEA, 1989). GC-MS was performed in a 30-m x 0.2-mm DB-5 capillary column in a temperature gradient $90-190^{\circ} \mathrm{C}\left(20^{\circ} \mathrm{C} \mathrm{min}^{-1}\right), 190-210^{\circ} \mathrm{C}\left(1{ }^{\circ} \mathrm{C} \mathrm{min}^{-1}\right)$, $210-300^{\circ} \mathrm{C}\left(25^{\circ} \mathrm{C} \mathrm{min}^{-1}\right)$ in $\underline{\mathrm{A}}$ a Fisons 8000 system in electron impact mode, and $\underline{\mathrm{B}}$ a VG autospek Q system in chemical ionisation mode to show molecular ions of derivatised monosaccharides. Spectra were obtained at an ionising potential of $70 \mathrm{eV}$ and a source temperature of $250^{\circ} \mathrm{C}$. The GC-MS injector temperature was set at $350^{\circ} \mathrm{C}$.

\section{RESULTS AND DISCUSSION}

Paper chromatography of honeydew revealed sugars with chromatographic mobilities corresponding to tri-, tetra- and penta-saccharides. The molecular masses of permethylated tri-, tetra- and penta-saccharides confirmed that they were all hexose polymers with molecular-ions in FAB-MS of $\mathrm{m} / \mathrm{z} 658$, 862 and $1067(\mathrm{M}+\mathrm{Na}=681,885$ and 1090), respectively (Figure 1).

The tri-, tetra- and penta-saccharide in Stigmacoccus sp. honeydew appeared identical to the analogous components of $\boldsymbol{C}$. hesperidum honeydew.

From the ion-current intensities of components of tri-, tetra-, and penta-saccharides were revealed a systematic increase in the proportion of 1,4-glucopyranose to 2-fructofuranose and 1glucopyranose with each unitary increase in the number of monosaccharides (Figure 2).

Linkage analysis by GC-MS fragment (Figure 3) showed for both Stigmacoccus sp. and $\boldsymbol{C}$. hesperidum oligosaccharides, fructofuranose linked in the 2 position, glucopyranose linked in both 1 and 4 positions and glucopyranose linked in the 1 position, as it is in sucrose, indicating the presence of an "Stigma" series of compounds.

Since these oligosaccharides also appear to be novel sugars (LIPTAK et al., 1991), structures were proposed for these oligosaccharides (Figure 4). The common names "Stigmatriose, Stigmatetraose and Stigmapentaose" are suggested for these sugars 


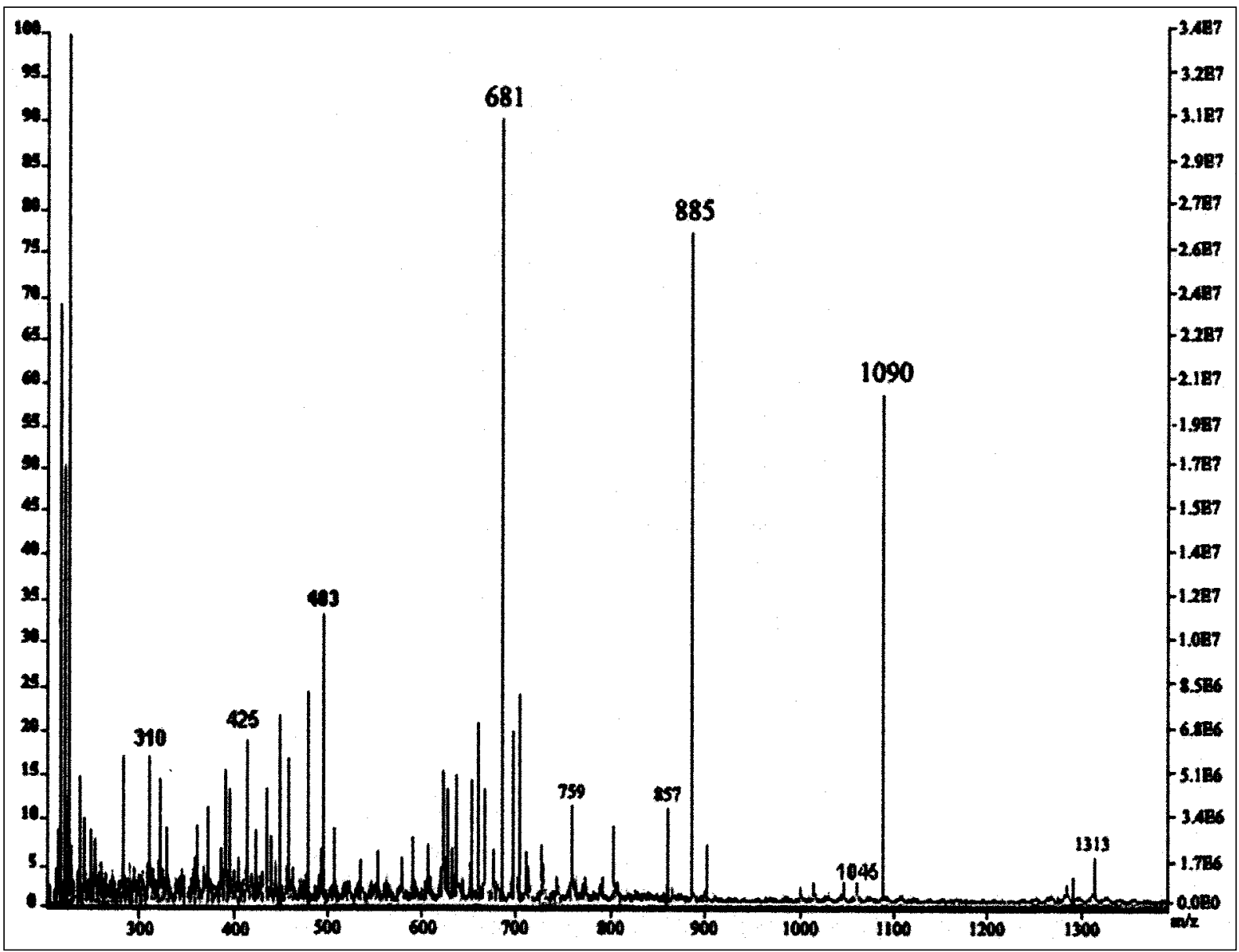

Figure 1 - FAB-MS of permethylated oligosaccharides from Stigmacoccus sp. The ions m/z 681,885 and 1090 belong to tri-, tetra- and penta-saccharides, respectively.

because they were found initially in Stigmacoccus sp. honeydew.

Analysis of the phloem sap from the host plant of the Stigmacoccus sp. and C. hesperidum, obtained by excising the scale insect in situ to leave embedded mouth parts, showed that sucrose and glucose were the only sugars. There was no evidence of any of the oligosaccharides which has been recognised in the excreted honeydew.

Trehalose and trehalulose have already been described as components of Myzus persicae (FISHER et al., 1984) and B. tabaci's honeydew (BATES et al., 1990). However, the occurrence of maltose, trehalose, trehalulose and a hexose-hexitol appear to be unique findings for scale insects, extending the range of natural occurrence of these sugars.

The significant difference between the composition of excreted honeydew and the plant sap is attributed to metabolism within the scale insect. At present it is not possible to differentiate between activity by the insect's enzymes and those of any microbial symbionts such as were described for other Coccoidae (DAVIDSON et al., 1994; BATES et al., 1990). However, the present application of modern analytical techniques to even very small amounts of natural material demonstrates the potential for recognising and discovering minor components in very small volumes of scale insect excreta. It also emphasises the complex biotransformations within scale insects, which in the present example of Stigmacoccus sp. form an integral part of a food web involving a wide range of flying insects. Such insects are seen to feed on the clear colourless honeydew droplets at the end of the long wax anal filaments of insects attached to the bark of large forest trees in Brazil.

Demonstration by linkage analysis should therefore justify full recognition of the "Stigma" series

Ciência Rural, v. 33, n. 4, jul-ago, 2003. 


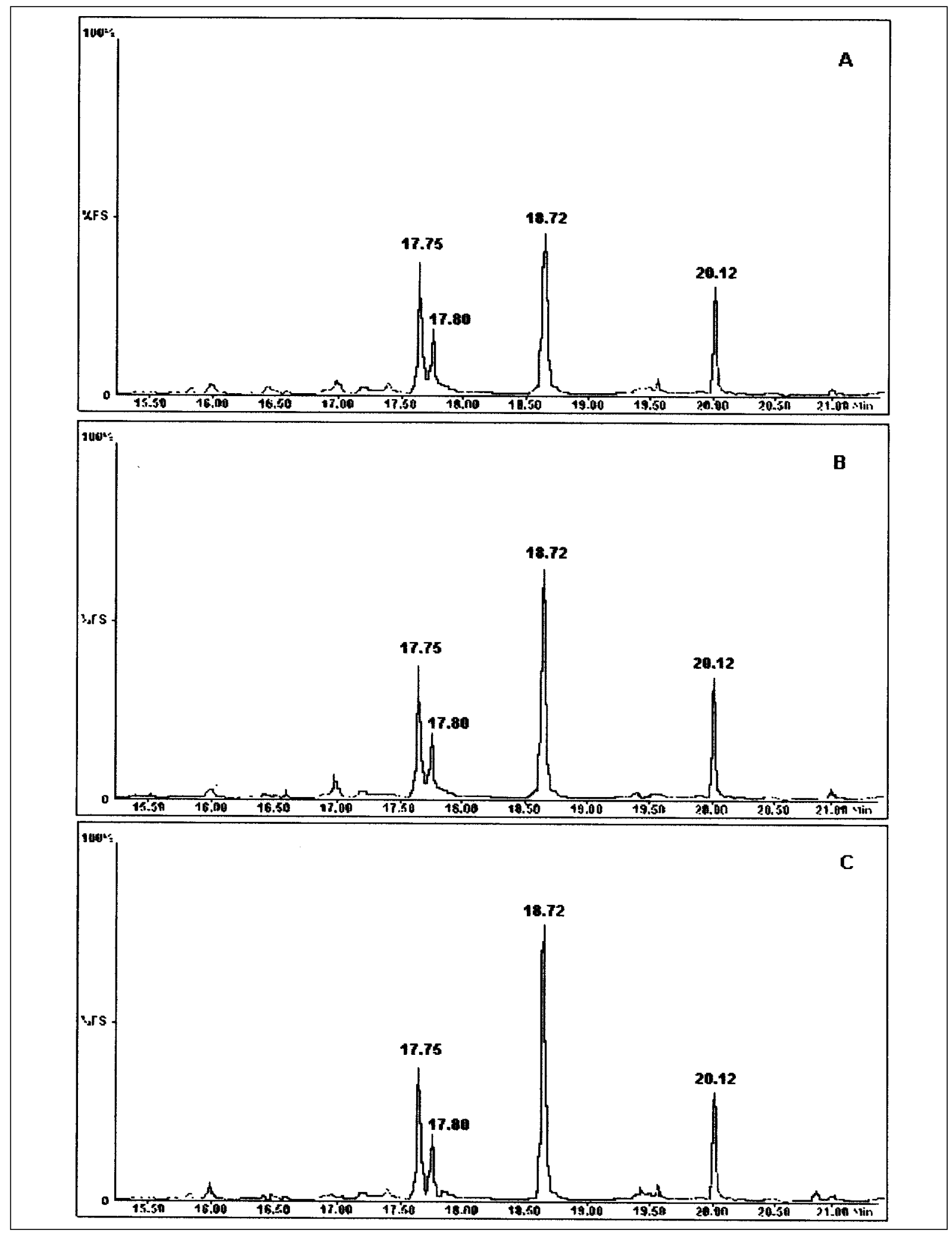

Figure 2 - Gas-chromatography retention times of monosaccharides from Stigmatriose (A), Stigmatetraose (B) and Stigmapentaose (C), showing total ion chromatogram of 2-fructofuranose $(17.75 \mathrm{~min})$, 1-glucopyranose $(18.72 \mathrm{~min})$ and 1,4-glucopyranose $(20.12$ $\min )$.

Ciência Rural, v. 33, n. 4, jul-ago, 2003. 


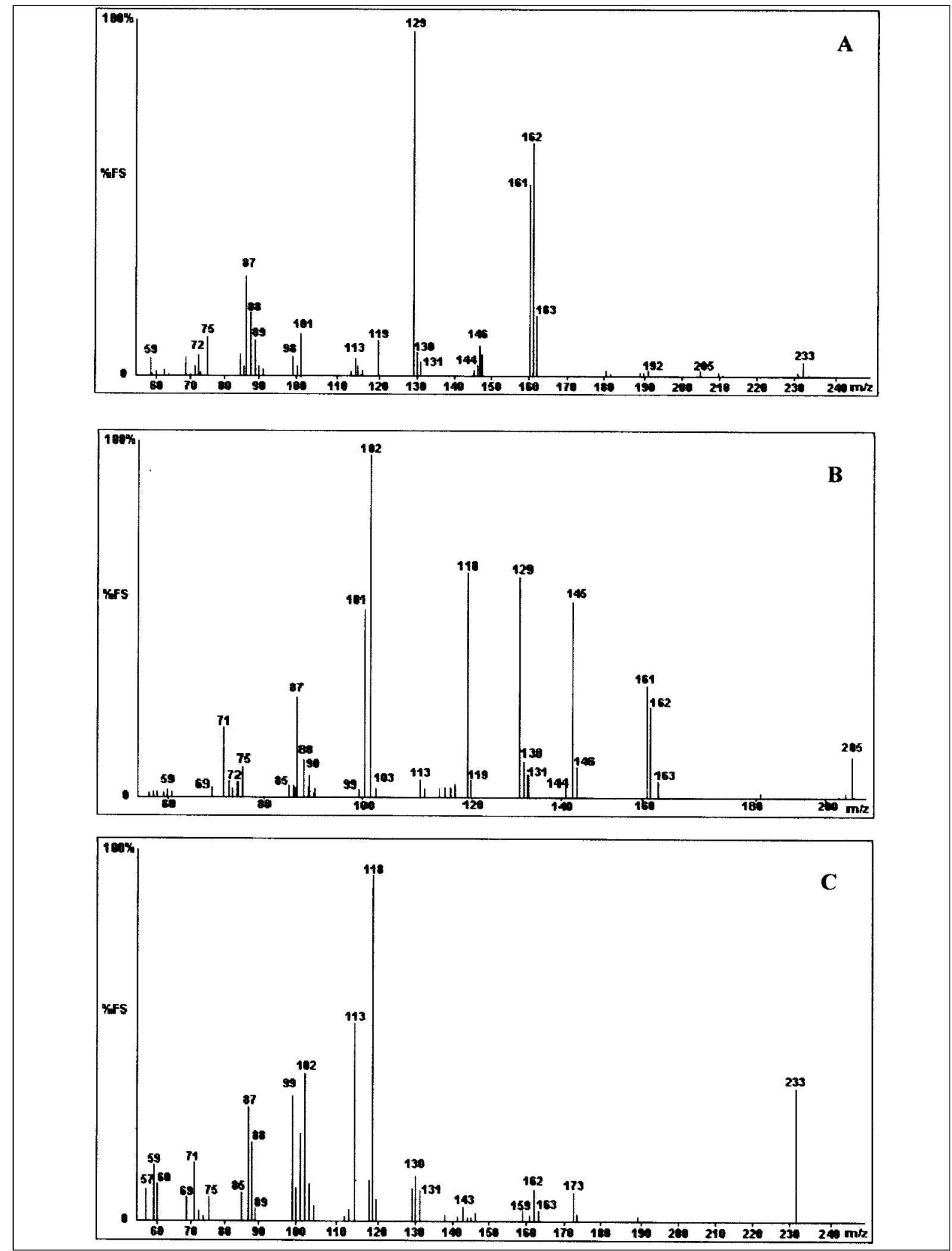

Figure 3 - Mass spectra of 2-linked fructofuranose with retention time (Rt) at 17.75 min (A), 1-linked glucopyranose with Rt at 18.72 min (B) and 1,4-linked glucopyranose with Rt at $20.12 \min (\mathrm{C})$

Ciência Rural, v. 33, n. 4, jul-ago, 2003. 

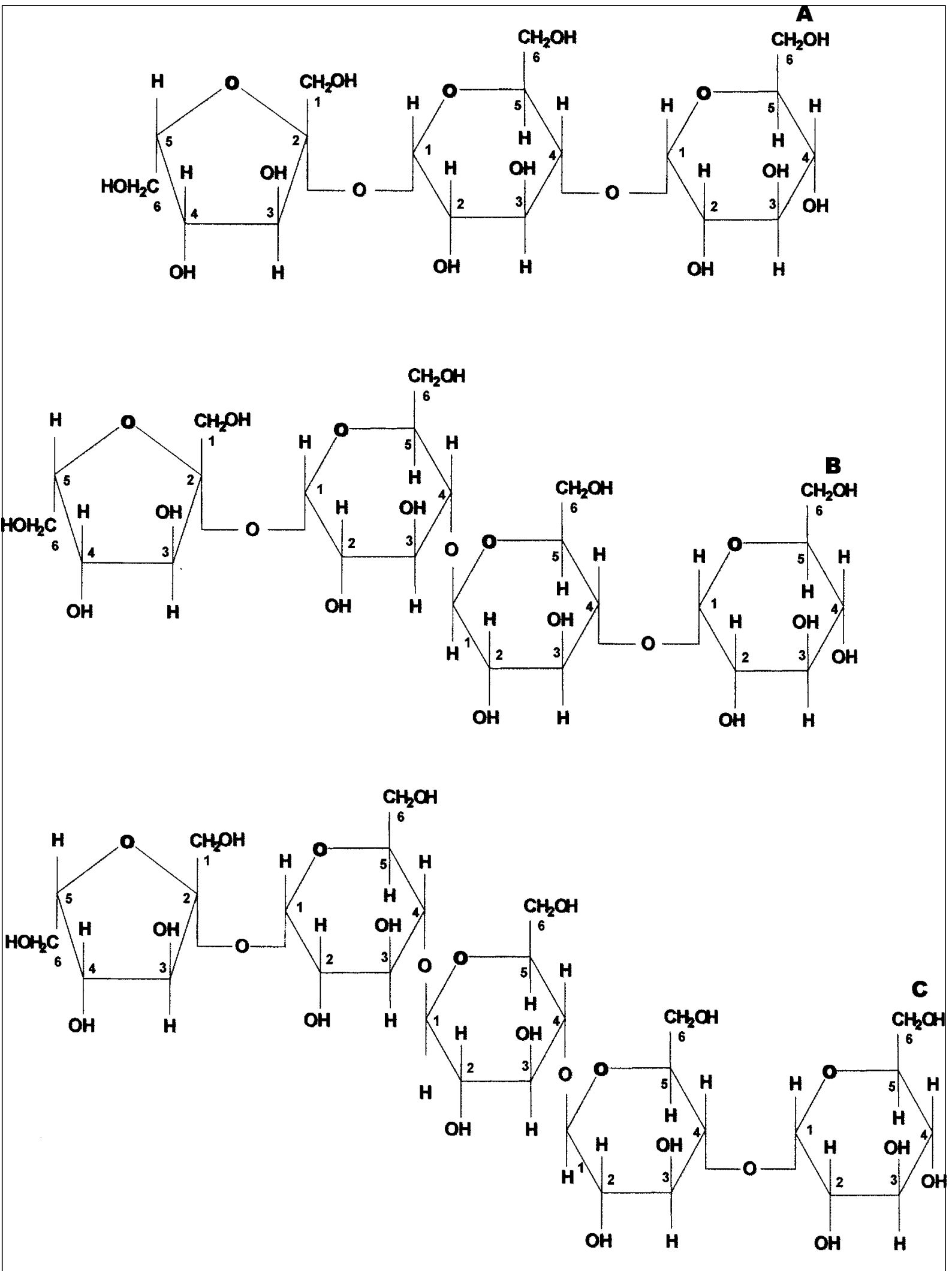

Figure 4 - Proposed structures of Stigmatriose (A), Stigmatetraose (B) and Stigmapentaose (C).

Ciência Rural, v. 33, n. 4, jul-ago, 2003. 
of oligosaccharides and the use of the trivial names. Also between the two quite different scale insects a common pattern of oligosaccharides is seen to exist

\section{ACKNOWLEDGEMENTS}

The author wish to thank Dra Gilian Watson, CABI BIOSCIENCE, Entomology Department, The Natura History Museum, London, UK for identify the scale insect.

\section{REFERENCES}

BATES, R. B. et al. N.m.r characterization of trehalose from the excrement of the sweet potato whitefly, Bemisia tabaci. Carbohydrate Research, v.201, p.342-345, 1990.

BOGO, A. Biochemical physiopathology of some ergot fungi and other honeydew-producing plant parasites. 2001. 141f. Thesis (PhD on Plant Pathology and Biochemistry) - Imperial College of Science, Technology and Medicine, London, UK.

BOGO, A.; WATSON, G.W.; MANTLE, P.G. Honeydew sugars eliminated by Stigmacoccus nr. asper Hempel (Hemiptera: Margarodidae) feeding on leguminous trees in Brazil. Entomologica, Bari, Italy, v.33, p.275-278, 1999.

BYRNE, D.N.; MILLER, W.B. Carbohydrates and amino acid composition of phloem sap and honeydew produced by Bemisia tabaci. Journal of Insect Physiology, v.36, p.433439, 1990 .
CARPITA, N.C.; SHEA, E.M. CRC analysis of carbohydrates by GLC and MS. New York : CRC, 1989. Cap. 4, p.145-189.

DAVIDSON, E.W., et al. Microorganisms Influence the composition of honeydew produced by the silverleaf whitefly, Bemisia argentifolii. Journal of Insect Physiology, v.40, p.1069-1079, 1994.

DELL, A. et al. Methods in enzymology. London : Lennarz \& Hart, 1994. p.231-276, 1994.

FISHER, D.B.; WRIGHT, J.P.; MILLER, T.E. Osmoregulation by the aphid Myzus persicae: A physiological role for honeydew oligosaccharides. Journal of Insect Physiology, v.30, p.387-393, 1984

GRAY, H.E.; FRAENKEL, G. Fructomaltose, a recently discovered trisaccharides isolated from honeydew. Science, v.118, p.303-305, 1953.

HENDRIX, D.L.; WEI, Y. Bemisiose: an unusual trisaccharide in Bemisia honeydew. Carbohydrate Research, v.253, p.329-334, 1994

ISAACS, R.; BYRNE, D.N.; HENDRIX, D.L. Feeding rates and carbohydrate metabolism by Bemisia tabaci (Homoptera: Aleyrodidae) on different quality phloem saps. Physiological Entomology, v.23, p.241-248, 1998.

LIPTAK, A. et al. CRC handbook of oligosaccharides. V. II - Trisaccharides. Boston : CRC, 1991. p.95-97.

WHITE, J. W.; MAHER, J. $\alpha$-maltosyl $\beta$ - $D$-fructofuranoside, a trisaccharide enzymically synthesized from sucrose. Journal American Chemical Society, v.75, p.1259, 1953. 